\title{
Ankilozan Spondilit Tanılı Hastada Postoperatif Gelişen Spondilodiskit
}

Postoperative Spondylodiscitis in a Patient With Ankylosing Spondylitis Diaphragmatic Rupture

\author{
Ümit YALÇIN', Şebnem Koldaş DOĞAN', Tuncay ÇAKIR', \\ Naciye Füsun TORAMAN ${ }^{1}$, Sevtap BADIL ${ }^{1}$, İlhan SEZER ${ }^{1}$ \\ 'Antalya Eğitim ve Araştırma Hastanesi Fiziksel Tıp ve Rehabilitasyon Kliniği, Antalya \\ Geliş Tarihi / Received: 24.07.2014 \\ Kabul Tarihi / Accepted: 18.08.2014
}

\section{ÖZET}

Bu olguda ankilozan spondilit tanısı olan, koksartroz nedeniyle sağ total kalça protezi cerrahisi geçirdikten sonra spondilodiskit gelişen hasta sunulmuştur. Cerrahi sonrası bacaklarda kuvvetsizlik, hareketle artan şiddetli bel ağrısı oluşan hastada parapleji gelişmesi sonucu çekilen manyetik rezonans görüntülemede torakal 11-12 vertebralar seviyesinde korda bası yapan spondilodiskit tespit edilmiş olup, hastaya T11 total laminektomi+kostatransversektomi uygulanıp, rehabilitasyon amaçlı servisimize yatırılmıştır. Etiyolojik bir neden bulunamamıştır. Tedavi sonrası alt ekstremite kas kuvvetleri düzelen hasta çift kanedyenle mobilize bir şekilde taburcu edilmiştir. Bu olguyu, cerrahi sonrası şiddetli bel ağrısı ve kas gücü kaybında tanı olarak spondilodiskiti de düşünmemiz ve ankilozan spondilitli hastalarda spondilodiskit komplikasyonunu hatırlatmak için hazırladık.

Anahtar Kelimeler: Ankilozan spondilit, postoperatif spondilodiskit, total kalça protezi.

\section{ABSTRACT}

In this case we present a patient with ankylosing spondylitis for 35 years who had spondylodiscitis after right total hip replacement operation. After right total hip replacement operation, patient had a progressive paraparesis of lower extremity, advanced to paraplegia, so we performed a thoracic magnetic resonance imaging which had spondylodiscitis with spinal cord compression at thoracic 11-12 vertebra levels. The patient is hospitalised for rehabilitation after T11 total laminectomy+costotransversectomy. We couldn't find any etiologic factor after our examination. Patient was discharged with better muscle strength with double crutches. We presented this case to remind spondylodiscitis after surgery and spondylodiscitis as a complication of ankylosing spondylitis.

Keywords: Ankylosing spondylitis, postoperative spondylodiscitis, total hip arthroplasty 


\section{Giriş̧}

Spondilodiskit, ankilozan spondilit (AS)'in iyi bilinen ancak nadir görülen bir komplikasyonudur. Sıklıkla AS'nin ileri dönemlerinde ortaya çıkar. Asemptomatik olabileceği gibi ciddi spinal kord hasarına da neden olabilir (1). Postoperatif spondilodiskit ise, genellikle invaziv spinal girişimler sonucunda oluşan, cerrahi sonrası bel ağrısı şikayeti gelişen hastalarda göz önünde bulundurulması gereken bir durumdur (2). Burada 35 senelik ankilozan spondilit tanısı olan, total kalça protezi cerrahisi ve ameliyat sırasında epidural kateter uygulanma öyküsü olup sonrasında spondilodiskit gelişen 61 yaşındaki kadın olgu sunulmuştur.

\section{OLGU}

H.A, 61 yaşındaki kadın hasta 35 senedir ankilozan spondilit öyküsü olup sağ kalça osteoartriti nedeniyle, yaklaşık 2 ay önce sağ total kalça protezi cerrahisi uygulanmış. Ameliyat sonrası progresif şekilde gelişen her iki bacakta kuvvetsizlik, sırtta istirahatle azalan hareketle artan tarzda ağrı şikayeti başlamış olup, ameliyattan yaklaşık 5 hafta sonra yürüyemez duruma gelmesinden dolayı dış merkeze başvurmuş. Manyetik rezonans görüntüleme (MRG)'de T11-T12 vertebralarda korda bası yapan spondilodiskit tanısı konulmuş (Şekil I). Bunun üzerine hastanemiz beyin cerrahisi bölümünde T11 total laminektomi ve kostatransversektomi ameliyatı uygulanmış. Ameliyat öncesi bakılan kan kültür-

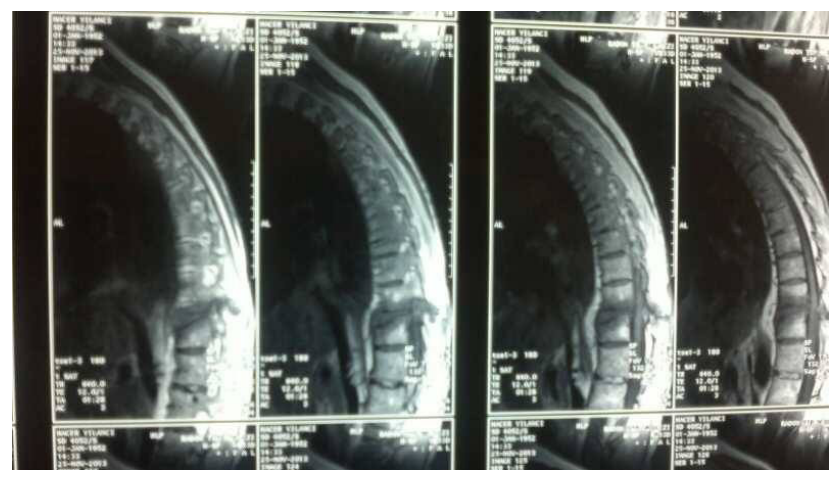

Şekil 1: Torakal spinal MRG'de T11-12'de ve intervertebral diskte $\mathrm{T} 2$ ağırlıkı kesitlerde sinyal artışı,T1 ağırlıklı kesitlerde sinyal intensitesinde azalma.

lerinde üreme olmamıştır, brucella (Rose Bengal ve TüpAgl) testleri negatif gelmiş. Ameliyat sırasında T11-12 disk mesafesinden, çevre dokulardan ve kemikten alınan örneklerde üreme olmamış. Aside rezistans basil (ARB) aranması ve M.Tüberkülozis polimerize zincir reaksiyonu
(PCR) çalışması negatif olup hastaya postop dönemde intaniye önerisiyle başlanan intravaskuler ampirik ampisilin sulbaktam tedavisi etken saptanamayınca 10 güne tamamlanıp kesilmiş. Cerrahi seviyeden alınan doku örneği patoloji sonucu 'lenfohistiositik kronik tipte hücre infiltrasyonu izlenen örneklerde neoplastik gelişim yoktur' şeklinde yorumlanmış. Genel durumu iyi olan ve alt ekstremitede ameliyat sonrası aktif hareket saptanan hasta, rehabilitasyon amacıyla servisimizce devralınmıştır. Servisimize yattığında hastanın fizik muayenesinde servikal rotasyonlar kısıtlı, çene-sternum mesafesi $8 \mathrm{~cm}$, göğüs ekspansiyonu $3 \mathrm{~cm}$, el-yer mesafesi 32 $\mathrm{cm}$, oksiput-duvar mesafesi $17 \mathrm{~cm}$, tragus-duvar mesafesi $24 \mathrm{~cm}$ 'di. Sakroiliak kompresyon testi negatif, lomber blok mevcuttu. Sağ kalça iç rotasyonu 0 , fleksiyonu 90 derece, solda ise iç rotasyon 10, fleksiyon 100 derece olarak ölçüldü. Nörolojik muayenesinde derin tendon refleksleri bilateral normoaktif, hoffman bilateral negatif, plantar yanıt bilateral ekstansör yöndeydi. Alt ekstremite motor kas kuvvetleri Medical Research Council skalasına göre; kalça fleksiyonu sağda $2 / 5$, solda $3 / 5$, diz ekstansörleri sağda $3 / 5$, solda $4 / 5$, diğer kas kuvvetleri $5 / 5$ düzeyindeydi. Yüzeyel duyu, hafif dokunma ve iğne batırma olarak T11'den sonra hipoestezik, derin duyu ise normal olarak değerlendirildi. Anal duyu ve anal kontraksiyon mevcuttu ve spastisite yoktu. Hasta, ASIA skorlamasına göre inkomplet $D$ nörolojik seviyesi T10 olarak belirlendi. Ateşi, lomber bölgede Isı artışı ve ciltte renk değişikliği yoktu. Laboratuvar tetkiklerinde; eritrosit sedimantasyon hızı (ESH) $55 \mathrm{~mm} /$ saat, c reaktif protein (CRP) $40.9 \mathrm{mg} / \mathrm{L}$, hemoglobin 11.2 g/dl, lökosit 7200 mm3 (\%65 nötrofil, \%21 lenfosit, \%12 monosit), karaciğer ve böbrek fonksiyon testleri normaldi. İdrar kültüründe Enterococcus faecalis üremesi sonrası hastaya ampisilin sulbaktam 4x1.5 gram i.v başlandı. Fonksiyonel durum olarak hasta yatak kenarında kısa bacak desteksiz oturabilme seviyesindeydi. Şiddetli kalça ve sırt ağrısı olan hastanın vizüel ağrı skoru (VAS) hareket halinde $100 \mathrm{~mm}$, istirahat halinde $80 \mathrm{~mm}$ olarak saptandı. Tedavi olarak, alt ekstremiteye yönelik aktif-asistif eklem hareket açıklığı egzersizleri, kalça kuşağını kuvvetlendirme, denge koordinasyon eğitimi, yürüme eğitimi, üst ekstremite kuvvetlendirme ve solu- 
num egzersizleri verildi. Kalça ağrısına yönelik burst tipi TENS ve hotpack verildi. Hastanın takiplerinde idrar kültürü steril geldi ve 10 günlük antibiyoterapisi kesildi. Ancak sedimentasyon hızında ve CRP seviyesinde düşme gözlenmemesi, sırt ve bel ağrılarının devam etmesi üzerine malignite, enfeksiyon açısından PPD yapıldı, ön-arka akciğer grafisi çekildi, tümör belirteçleri olarak ca 15-3, ca 19-9, ca 125 seviyelerine bakıldı ancak patoloji saptanmadı. Servikal, torakal, lomber MRG, tüm vücut kemik sintigrafisi çekildi. Torakal MRG; T11-T12 disk mesafesi özellikle anteriorda ekspanse görünümde, disk intensitesi T2 sekanslarda artmış, disk posteriorunda parasantral protüzyon mevcut olup korda bası yorumlanırken (Şekil II), İntravenöz kontrast madde sonrası disk mesafesinde, end platelerde eşlik eden anterior ve posteriordaki yumu-

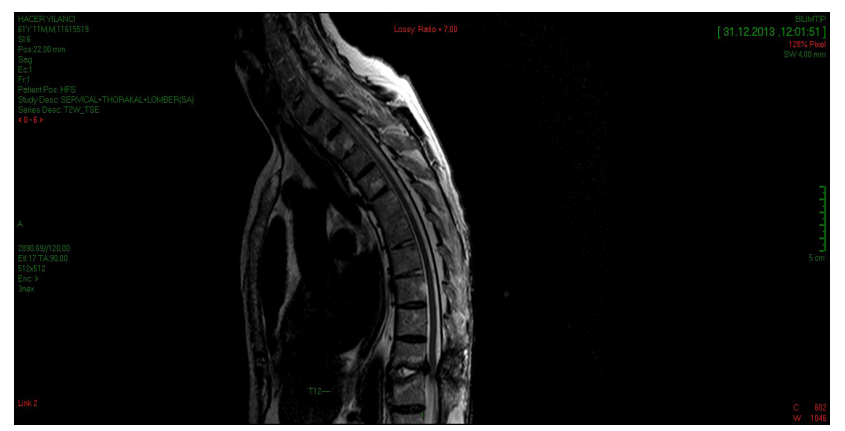

Şekil 2: T11-T12 disk mesafesi özellikle anteriorda ekspanse görünümdedir. Disk intensitesi T2 sekanslarda artmıştır. Disk posteriorunda parasantral protüzyon mevcut olup korda bası izlendi.

şak doku komponentlerinde yoğun kontrastlanma (spondilodiskit+epidural apse) şeklinde yorumlanırken, servikal ve lomber MRG'lerinde belirgin patoloji saptanmadı. Tüm vücut kemik sintigrafisi; 'T11-12 vertebra intervertebral alanda lineer tarzda hafif düzeyde (spondilodiskit?) ve bilateral interartiküler alanda fokal (geçirilmiş operasyona sekonder değişiklikler?, enfeksiyon?) artmış aktivite tutulumları izlenmiştir' şeklinde raporlanmıştır. Akut faz reaktanlarında artışın devam etmesi ve torakal MRG'de apse görünümünün olmasından dolayı yeniden cerrahi girişim açısından beyin cerrahisine, spondilodiskite yönelik antibiyoterapi tedavisi açısından da intaniyeye danışıldı. Danışılan bölümler tarafından tedaviye yönelik ek öneri sunulmadı. Taburculuk sonrası poliklinik kontrolü önerildi. Takipler sırasında hastanın alt ekstremite kas kuvveti solda global 5/5, sağda ise kalça fleksiyonu ve diz fleksiyonu $4 / 5$ seviyeseviyesine iler- ledi. Yüzeyel duyu seviyesi T12'ye ilerledi. ASIA skoru inkomplet $D$, nörolojik seviye T12 olarak gelişme gösterdi. Önce walker ile, daha sonra kanedyen ile mobilizasyonu sağlanan hastanın 15 seanslık tedavisi sonrası kalça ağrısı belirgin seviyede azaldı ve vizüel ağrı skoru, hareket halinde iken $30 \mathrm{~mm}$, istirahat halinde iken 10 mm'ye kadar geriledi. Şikayetleri gerileyen, çift kanedyenle mobilizasyon hedefine ulaşılan, kalça ağrısında belirgin azalma saptanan hasta 1 ay sonra poliklinik kontrolüne gelecek şekilde taburcu edildi. Taburculuk sonrası kontrole gelen hastanın ESH düzeyi $35 \mathrm{~mm} / \mathrm{saat}$, CRP düzeyi 7 mg/L'ye gerilediği tespit edildi. Hastanın total kalça artroplastisinden önce çekilmiş bir MRG'si olmamasına rağmen şikayetlerinin ameliyattan bir süre sonra aniden başlaması ve akut faz reaktanlarındaki yükselme hastada ameliyata sekonder gelişmiş, kendini sınırlayan bir enfeksiyonu düşündürmüştür. Hastada enfeksiyon varlığını tam olarak ekarte edemediğimiz, dolayısıyla antienflamatuvar ilaç kullanmamamıza rağmen akut faz reaktanlarındaki düşme eğilimi bu klinik tablonun ankilozan spondilite bağlı bir komplikasyon olmadığını düşündürdü.

\section{TARTIŞMA}

Spondilodiskit, toplum kaynaklı veya nozokomiyal enfeksiyonların genellikle kan yolu ile uzak bir yerden yayılım ile, tanı ve tedavi amaçlı yapılan spinal girişimler sonucunda oluşabileceği gibi ankilozan spondilit gibi nonenfeksiyöz nedenlerden sonra da oluşabilmektedir $(3,4)$.

Spondilodiskitli hastalarda en sık izole edilen mikroorganizma S.aureus'tur. Bunun dışında gram (-) bakteriler, streptokoklar, Brucella melitensis, Mycobacterium tuberculosis'tir. İmmünsüpresyon, diabetes mellitus, alkolizm, steroid tedavisi, kronik böbrek yetmezliği, intravenöz ilaç kullanımı, kateterizasyon, penetran yaralanmalar, operasyon sonrası fazla kanama olması ve disk herniasyonuna bağlı vertebral son plaklar kürete edilmesi, predispozan faktörlerdir (5-7). Bizim hastamızda uzun yıllardır düzensiz steroid kullanma öyküsü ve kalça protez cerrahisi sırasında epidural kateterizasyon öyküsü mevcuttu. 
Postoperatif spondilodiskit sinsi gelişmekte olup ağrı ve nörolojik defisit gibi bulgular genellikle cerrahinin başarısızlığına bağlanmaktadır (5). Semptom ve bulguların gelişimi cerrahi sonrası 3 ay içerisinde ortaya çıkmaktadır (7). Hastamızın ise şikayetleri ameliyat sonrası başlamış olup, kalça protezi cerrahisinden yaklaşık 5 hafta sonra spondilodiskit tanısı konmuştur.

Postoperatif spondilodiskitleri de septik ve aseptik spondilodiskit şeklinde gruplandırmak mümkündür. Septik spondilodiskitlerde hematolojik bulgular çok spesifik olmamakla beraber, ESH ve CRP hemen tüm olgularda artmıştır. Daha az görülen aseptik spondilodiskit ise, disk mesafesinin operasyon sırasında kontaminasyonu ile gelişen, enfeksiyonun kendi kendini sınırladığı, kültür ve diskal biyopsilerde patojenin üretilemediği, ağır olmayan bir klinik tablodur. ESH ve CRP normal veya hafif artmış olabilir $(5,7,8)$. Olgumuzda da alınan kan, kemik, yumuşak doku kültürlerinde üreme olmayıp, poliklinik kontrolüne geldiğinde $\mathrm{ESH}$ ve CRP seviyelerinin normal sınırlara geldiği görülmüştür.

Postoperatif spondilodiskit vakalarının \% 15 kadarında yeni nörolojik defisit veya mevcut nörolojik defisitte artış olmaktadır (9). Bizim hastamızda da kalça protezi cerrahisinden sonra progresif gelişen alt ekstremitede motor ve duyu defisiti vardı.

Etkenlere yönelik spondilodiskit özellikleri de klinik ve laboratuvar olarak farklılıklar gösterebilmektedir. Biyopsi kültürlerinde olguların \%43-78'inde patojen üremektedir (10). Hastamızın hem spondilodiskit operasyonu öncesi ve operasyon sırasında alınan kültürlerinde, hem de servisimizde yattığı dönem içerisinde alınan kültürlerinde üreme saptanamadı. Brucella spondilodiskiti açısından bakılan Rose Bengal, Brucella Wright tüp aglütinasyon testleri, tüberküloz spondilodiskiti açısından bakılan PPD, ARB aranması, M.tüberkülozis PCR çalışmaları (-) geldi.

Postoperatif spondilodiskit vakalarında radyolojik bulgular, klinik ve laboratuar bulgularından daha geç ortaya çıkmaktadır. Direkt radyografi bulguları genellikle 4-6. haftalardan sonra gö- rülmeye başlar. Günümüzde en önemli ve en erken tanı aracı olarak MRG tercih edilmektedir (11). Hastamızın da MRG bulguları spondilodiskit ile uyumluydu.

Spondilodiskit, ankilozan spondilitin geç komplikasyonu olarak da karşımıza çıkabilmektedir. Sıklıkla akut başlangıçlı, o zamana kadar alışık olunan ağrı karakterinin aksine hareketle artıp istirahatle azalan lokalize ağrı ile karakterize olup en sık torakal ve lomber bölgede saptanır (12-13). Prevalansı \%1-\%10 arasında değişmektedir (12). Ankilozan spondilitte spondilodiskit patogenezi günümüzde halen tartışmalı bir konudur. Travma, mekanik faktörler ve inflamasyon bu konuda suçlanan faktörlerdir (12). Ayrıca tanıda bakteriyel enfeksiyonlar, malignite ve travmatik olayların dışlanması gerekir. Asemptomatik bir klinikten paraplejiye kadar değişken bir kliniğin olması ve radyolojik bulgulardaki çeşitlilik etyopatogenezin multifaktöryel olduğunu göstermektedir (12).

Ankilozan spondilite bağlı spondilodiskitte spinal kord kompresyonu yaygın bir bulgu değildir. Yapılan bir araştırmada 1980 ile 2007 yılları arası literatürler taranmış AS'ye bağlı spondilodiskitten dolayı 5 tane kord kompresyonu vakası bildirilmiştir (13). Bu vakaların hepsinin erkek olduğu ve hepsinde torakal tutulum olduğu bildirilmiştir. 5 vakanın 2'sinde paraparezi gelişmiş olup 4'ünde üriner disfonksiyon, 2'sinde de alt ekstremitede motor kuvvetsizlik bildirilmiştir. Bizim hastamızda da bu tip bir ağrı karakteri ve torakal bölge tutulumu mevcuttu. Enfeksiyonun ekarte edilememesi, akut faz yanıtlarının, antienflamatuvar tedavi verilmemesine rağmen gerilemesi, MRG ve sintigrafide enfeksiyonu düşündürecek bulguların olmasından dolayı, hastamızda ankilozan spondilite bağlı spondilodiskitten ziyade, total kalça artroplastisi sırasında epidural kateter ve uzun süreli steroid kullanımı gibi predispoze faktörler zemininde gelişen kontaminasyona bağlı enfeksiyonun kendini sınırladığı aseptik bir spondilodistik tablosu olabileceğini düşündük.

Postoperatif spondilodiskitin tedavisinde genel kabul görmüş bir protokol henüz yoktur (9). Antibiyotik tedavisi ve yatak istirahati, en iyi tedavi gibi görünmektedir (14). Diskit bulgularının ilerleyip nörolojik defisitin ortaya çıktığı durumlarda cerrahi planlanmalıdır. Hastamızda 
da alt ekstremitede motor ve duyu defisiti geliştiği için opere edilmiştir. Etiyolojik ajanın ortaya konamadığı durumlarda, en sık etiyolojik ajanın stafilokoklar olduğu düşünülerek, uygun antibiyotik seçimi yapılmalıdır. Hastada semptomlar azalana kadar immobilizasyon sağlanmalı ve semptomlar yatıştıktan sonra da korse veya ortez kullanılarak mobilize edilmelidir (11). Mastronardi ve ark.' nın (7) çalışmasında, spondilodiskit aseptik olsa bile, en sık patojen mikroorganizmanın gram pozitifler ve özellikle de Stafilokokkus aureus olduğu göz önüne alınarak, buna yönelik antibiyotik tedavisi başlanması gerektiği vurgulanmıştır. Ancak bizim hastamızda sadece preop dönemde 1 hafta ampirik ampisilin sulbaktam tedavi öyküsü bulunmakta olup, daha sonra buna yönelik antibiyoterapi almamıştır.

\section{SONUÇ}

Postoperatif spondilodiskit sıklıkla spinal girişimler sonrası oluşur. Bu nedenle cerrahi sonrası sırtta başlayan ağrı şikayetinden mutlaka spondilodiskit de akla gelmelidir. Daha önceki sırt ağrılarından farklı bir şekilde ağrı karakteri tarifleyen ankilozan spondilitli hastalarda da spondilodiskit tanısını akılda tutmakta fayda vardır.

\section{KAYNAKLAR}

1. Atan Ç, Seçkin Ü, Bodur H. Ankilozan spondilite bağlı spondilodiskit. Turk J Phys Med Rehab 2008;54(2):77-8.

2. Bavinzski G, Scheggl A, Trattnig S, et al. Microsurgical management of postoperative disc space infection. Neurosurg Rev. 2003; 26:102-7,

3. Friedman JA, Maher CO, Quast LM, et al. Spontaneous disc space infections in adults. Surg Neurol 2002;57(2): 81-6.

4. Hopkinson N, Stevenson J, Benjamin S. A case ascertainment study of septic discitis: clinical, microbiological and radiological features. QJM 2001;94(9):465-470.

5. Jimenez-Mejias ME, De Dios Colmenero J, Sanchez-Lora FJ, et al. Postoperative spondylodiskitis: etiology, clinical findings, prognosis, and comparison with nonoperative pyogenic spondylodiskitis. Clin Infect Dis 1999;29(2):339-45.

6. Van Tassel P. Diagnostic imaging of spinal infection. In: Batjer HH, Loftus CM (Editors). Textbook of neurological surgery.New York: Wolters Kluwer, 2003;3224-38.

7. Mastronardi L, Rychlicki F, Tatta C, et al. Spondylodiscitis after lumbar microdiscectomy: effectiveness of two protocols of intraoperative antibiotic prophylaxis in 1167 cases. Neurosurg Rev 2005;28:303-7.

8. Fouquet $B$, Goupille $P$, Jattiot $F$, et al. Discitis after lumbar disc surgery. Features of "aseptic" and "septic" forms. Spine 1992;17:356-8.

9. Silber JS, Anderson DG, Vaccaro AR, et al. Management of postprocedural discitis. Spine J 2002;2(4):279-87.

10. Gouliouris T. Spondylodiscitis: update on diagnosis and management. J Antimic Chemotherapy 2010;65( suppl 3):11-24.

11. Çerçi A, Özer AF. Postoperatif diskitis ve tedavisi. In: Zileli M, Özer AF (Editors). Omurilik ve omurga cerrahisi. izmir: META Basım, 2002;783-7.

12. Rasker JJ, Prevo RL, Lanting PJ. Spondylodiscitis in ankylosing spondylitis, inflammation or trauma? A description of six cases. Scand J Rheumatol 1996;25(1):52-7.

13. Toussirot $E$, Chataiqner $H$, Pepin $L$, et al. Spinal cord compression complicating aseptic spondylodiscitis in ankylosing spondylitis. Clin Exp Rheumatol. 2009;27(4):654-7.

14. Asamoto $S$, Doi $H$, Kobayashi $N$, et al. Spondylodiscitis: diagnosis and treatment. Surg Neurol 2005;64(2):103-8. 